\title{
POTRET PERISTIWA TINDAK TUTUR DALAM KEGIATAN FORUM KERUKUNAN UMAT BERAGAMA (FKUB) LAMPUNG TIMUR
}

\author{
Ani Susilawati \\ email:anyfsusilawati@gmail.com \\ Akhadiyatus Sholihah. TS, M.Pd \\ email: akhadiyatussholihah.teil@gmail.com \\ Institut Agama Islam Negeri (IAIN) Metro \\ Jl. Ki Hajar Dewantara, Iringmulyo, Metro Tim., \\ Kota Metro, Lampung 34381
}

\begin{abstract}
Abstrak
Penelitian ini menjelaskan tentang potret peristiwa tindak tutur dalam kegiatan forum kerukunan umat beragama (FKUB) Lampung Timur. Tujuan dari penelitian ini adalah untuk mengetahui potret tindak tutur dalam kegiatan Forum Kerukunan Umat Beragama (FKUB) di Lampung Timur. Jenis penelitian ini adalah penelitian kualitatif yang menggunakan pendekatan pragmatik dengan menerapkan metode deskriptif kualitatif. Metode ini digunakan untuk menggambarkan peristiwa tutur dan tindak tutur yang terjadi sesuai dengan data yang penulis kumpulkan. Untuk melengkapi kesempurnaan data penulis menggunakan metode teknik simak dan cakap. Dari kedua metode tersebut penulis menggunakan beberapa teknik yaitu instrumen, teknik rekam dan teknik catat. Setelah penggalian data, langkah selanjutnya adalah pengolahan sekaligus analisis data dengan menggunakan langkah-langkah sebagai berikut; pertama transkrip data yang mengandung tindak tutur terlebih dahulu ditranskripsikan ke dalam bahasa tulis. Kedua Memasukkan data hasil trnaskrip ke dalam kartu data. Ketiga Analisis data berdasarkan beberapa aspek yang telah penulis lakukan. Keempat Pengklasifikasian data berdasarkan jenis peristiwa tutur dan tindak tutur. Berdasarkan hasil analisis data penelitian dapat disimpulkan bahwa tindak tutur yang digunakan dalam Forum Kerukunan umat beragama adalah tindak tutur lokusi, tindak tutur perlokusi, dan tindak tutur llokusi yang terdapat empat bentuk yaitu 1) asertif (Menyatakan, Menyarankan, mengingatkan). 2) direktif (memerintah, merekomendasi). 3) ekspresif (berterima kasih, meminta maaf, berbelasungkawa). 4) komisif (menawarkan sesuatu).
\end{abstract}

Kata Kunci: Tindak Tutur, Lokusi, Ilokusi, Perlokusi 


\begin{abstract}
This study describes the portrait of speech acts in the East Lampung religious harmony forum. The aim of this research is to know the portrait of the speech act in the activities of the Religious Harmony Forum (FKUB) in East Lampung. The type of this research is qualitative research that uses a pragmatic approach by applying descriptive qualitative methods. This method is used to describe speech events and speech acts based on the data that has been collected by the writer. To complete the data the writer uses listening technique method and proficient technique. From the two methods the writer uses several techniques, namely instruments, recording technique and writing technique. After extracting the data, the next step is processing and analyzing data by using the following steps; the first data transcript containing the speech act which is transcribed into written language. Second puts the results of the data into the data card. Third, the writer analysis the data based on several aspects that has done by the writer. Fourth, the classification of the data based on the type of speech events and speech acts. Based on the results of the research data analysis, it can be concluded that the speech acts used in the Forum of Religious Harmony are locution of speech acts, perlocution of speech acts, and illocution of speech acts which have four forms, namely 1) assertive (declaring, suggesting, reminding). 2) directive (rule, recommend). 3) expressiveness (thanking, apologizing, condolence). 4) commissive (offering something).
\end{abstract}

Keywords: Speech Act, Locution, Illocution, Per locution

\title{
A. Pendahuluan
}

Setiap orang memerlukan komunikasi dengan orang lain, untuk mengadakan komunikasi itu, tentunya memerlukan alat, yaitu alat komunikasi. Bahasa adalah alat komunikasi yang terbaik. Namun, apabila dalam menggunakan bahasa itu sebagai alat komunikasi tidak tepat, atau tidak sesuai dengan hakikat maupun aturannya, proses komunikasi menjadi terhambat. Oleh karena itu, sangat diperlukan pengetahuan pemahaman, serta pengalaman dalam komunikasi berbahasa. ${ }^{1}$

Menurur Abdul Chaer dan Leonie Agustina bahasa sebagai alat komunikasi terdiri atas dua aspek, yakni aspek linguistik dan aspek

\footnotetext{
${ }^{1}$ Andiopenta Purba, Tindak Tutur Dan Peristiwa, Purba, Vol. 1 No. 1 Desember
} 2011, h. 77 
paralinguistik. Kedua aspek ini bekerja sama dalam membangun komunikasi bahasa. Aspek linguistik mencakup tataran fonologi, morfologi dan sintaksis. Ketiga tataran ini mendukung terbentuknya semantik. Aspek paralinguistik mencakup kualitas ujaran, unsur supra segmental seperti tekanan, nada dan intonasi, jarak dan gerak-gerik tubuh, rabaan yang berkenaan dengan indra perasa (kulit). Aspek linguistik dan paralinguistik ini berfungsi sebagai alat komunikasi bersama-sama dengan konteks situasi membangun situasi tertentu dalam proses komunikasi.

Dalam proses komunikasi itu, bahasa sebagai alat, baik aspek linguistik maupun aspek paralinguistik, informasi yang disampaikan, serta pihak partisipan sebagai pemberi informasi dan penerima informasi secara bersamasama membentuk apa yang disebut dengan tindak tutur dan peristiwa tutur dalam suatu situasi tutur.

Hakikat bahasa sebagai alat komunikasi yang digunakan dalam setiap aktifitas baik secara individual maupun sosial. Salah satu penggunaan bahasa dalam ranah sosial adalah yang terjadi pada Forum Komunikasi antar Umat Beragama di Lampung Timur, yang terus berlangsung dengan baik dengan adanya visi dan misi yang sama. Forum Komunikasi Umat Beragama adalah forum yang dibentuk oleh masyarakat dan difasilitasi oleh pemerintah dalam rangka membangun, memelihara dan memberdayakan umat beragama untuk kerukunan dan kesejahteraan. Forum ini dibentuk berdasarkan pada Peraturan Bersama Menteri Agama dan Menteri Dalam Negeri Nomor : 9 Tahun 2006 dan Nomor : 8 Tahun 2006.

Masyarakat adalah makhluk sosial yang selalu berinteraksi baik secara individual maupun sosial. Banyak peristiwa yang terjadi dalam proses interkasi tersebut, baik peristiwa positif maupun peristiwa negatif. Maraknya konflik sosial, pertikaian, perselisihan baik antar umat beragama maupun antara suku salah satu faktor penyebabnya adalah salahnya cara memaknai 
tuturan. Namun hal demikian dapat diminimalisir dengan menjaga komunikasi yang baik antara penutur dan lawan tutur.

Berikut salah satu contoh tuturan yang terjadi dalam rapat kemah pemuda lintas agama yang dipimpin oleh ketua pelaksana kegiatan tersebut. Contoh tuturannya adalah "mari kita mulai pertemuan ini dengan bersama-sama doa sesuai dengan kepercayaan kita masing-masing, berdoa mulai! ). Dalam tuturan tersebut mengandung beberapa aspek situasi tutur seperti: (1) Adanya penutur dan lawan tutur yaitu antara ketua pelaksana dengan anggota rapat yang berbeda baik dari agama, usia, latar belakang sosial, ekonomi, jenis kelamin dan lain-lain. (2) konteks tuturan mengacu pada pemahaman bersama tentang perbedaan agama yang ada. (3) tujuan tuturan tersebut untuk menjaga komunikasi dan toleransi antar agama.(4) tuturan berupa perbuatan, jadi dalam tuturan tersebut menggambarkan toleransi dan rasa menghargai antar agama karena hakikatnya tuturan itu adalah suatu tindakan. (5) tuturan sebagai suatu tindakan verbal, jadi tuturan yang berupa bahasa verbal itu merupakan suatu tindakan yang dimaksudkan untuk menjaga kominikasi yang abaik antara penutur dengan lawan tutur.

Forum Kerukunan Umat beragama adalah forum yang dibentuk dari berbagai macam agama baik dari tokoh masyarakat, tokoh adat dan para tokoh agama yang bekerja sama dalam membangun keharmonisan dan kesejahteraan hidup. Dengan kondisi dan latar belakang yang berbeda namun menyuarakan tujuan yang sama, yaitu membangun kerukunan antar agama tentunya bukan hal yang mudah. Terutama terkait dengan penggunaan bahasa dalam setiap kegiatannya, yang misinya untuk menegakkan kerukunan semua agama. Hal inilah yang manarik bagi peneliti untuk mengkaji lebih jauh bagaimana potret peristiwa tutur dan tindak tutur yang ada dalam kegiatan FKUB di Lampung Timur. 
Berkaitan dengan peristiwa tutur dan tindak tutur di atas, terdapat beberapa hasil penelitian terdahulu yang terkait dengan penelitian ini sebagai bahan pembanding dan penentu posisi penelitian ini yaitu: Pertama: Strategi kesopanan berbahasa Presiden joko widodo; potret tindak Tutur penanganan masalah Sosial-politik bangsa. Penelitian ini dilakukan oleh Burhanuddin dan Sumarlam. Penelitian ini mengkaji tentang Strategi kesopanan berbahasa jenis menghindari pertentangan dengan mitra tutur dan membuat penawaran-janji merupakan jenis strategi kesopanan yang sering digunakan oleh Presiden Joko Widodo masing-masing 20\% sedangkan yang jarang digunakan adalah jenis strategi memperhatikan minat, keinginan, kelakuan, atau barang $2 \% .{ }^{2}$ Kedua: Tindak Tutur Santun Sebagai Strategi Pemilihan Bahasa Untuk Komunikasi Konselor Yang Efektif. Penelitian ini dilakukan Ristiyani. Penelitian ini mengkaji tentang Tindak tutur santun sebagai strategi pemilihan bahasa untuk komunikasi konseling yang efektif sangat tepat. Terdapat tiga kaidah yang harus dipatuhi agar tuturan memiliki ciri santun. Ketiga kaidah itu yakni formalitas (formality), ketidaktegasan (hesitancy), kesamaan atau kesekawanan (equality). Intinya, dalam kaidah pertama terkandung maksud tuturan hendaknya harus bersifat formal, jangan terkesan memaksa, dan jangan terkesan angkuh. Pada kaidah kedua, terkandung makna agar penutur memberikan pilihan kepada mitra tutur, jangan terlalu tegas, atau bahkan bersifat kaku dalam bertutur, sedangkan pada kaidah ketiga terkandung makna agar penutur memperlakukan mitra tutur sebagai teman penutur. Sebagai seorang teman, si mitra tutur haruslah dapat merasa aman, sama, dan sejajar dengan si penutur. Penutur adalah konselor sedangkan mitra tutur adalah klien. Jadi, melalui pemilihan kaidah-kaidah dalam tindak tutur santun dapat

${ }^{2}$ Burhanuddin \& Sumarlam, Strategi kesopanan berbahasa Presiden joko widodo; potret tindak Tutur penanganan masalah Sosial-politik bangsa Adabiyyāt, Vol. XIV, No. 2, Desember 2015, h. 189 
menjadi alternatif strategi pemilihan bahasa untuk komunikasi konselor yang efektif. $^{3}$ Ketiga: Jenis dan fungsi tindak tutur dosen dalam interaksi pembelajaran bahasa arab di uin malang oleh Wahyudi dalam penelitian ini membahas bahwa dalam pembelajaran bahasa Arab, dosen menggunakan lima jenis tindak bahasa, yaitu tindak direktif, tindak asertif, tindak komisif, tindak ekspresif, dan tindak deklaratif. Porsi kelima jenis tindak bahasa tersbut tidak sama. Jenis tindak bahasa direktif menduduki peran dominan, kemudian asertif, komisif, ekspresif dan deklaratif. Oleh karena itu dosen mesti menempatkan dirinya bertindak sebagai fasilitator dan koordinator kelas. ${ }^{4}$

Jika dipahami dari beberapa penelitian di atas maka, posisi penelitian ini adalah mempunyai kesamaaan dengan beberapa penelitian yaitu kesamaan pada sisi kajian tindak tutur tetapi, objek, tujuan, dan situasi sosial dari penelitian ini yang berbeda. Sehingga kesimpulan dari penelitian ini melengkapi beberapa hasil penelitian tindak tutur yang sudah ada.

Berpijak pada realitas di atas penulis merasa perlu adanya kajian lebih mendalam berkaitan dengan peristiwa tindak tutur dalam kegiatan Forum Kerukunan Antar Umat Beragama dengan judul "Potret peristiwa tutur dan tindak tutur dalam kegiatan Forum Kerukunan Umat Beragama (FKUB) Lampung Timur.

\section{B. Landasan Teori}

Goerge Yule dalam buku pragmatik yang menjelaskan bahwa dalam usaha mengungkapkan diri seseorang tidak hanya menghasilkan tuturan yang mengandung kata-kata dan setruktur-setruktur gramatikal saja, tetapi mereka

3 Ristiyani, Tindak Tutur Santun Sebagai Strategi Pemilihan Bahasa Untuk Komunikasi Konselor Yang Efektif, Jurnal Konseling GUSJIGANG Vol. 2 No. 1 (JanuariJuni 2016), h. 49

${ }^{4}$ Wahyudi, Jenis dan fungsi tindak tutur dosen dalam interaksi pembelajaran bahasa arab di UIN Malang, ThaqÃfiyy ÃT, Vol. 13, No. 2, Desember 2012, h. 358 
juga memperlihatkan tindakan-tindakan melalui tuturan-tuturan itu. Tindakantindakan yang ditampilkan lewat tuturan biasanya disebut dengan tindak tutur dan dalam bahasa Inggris secara umum diberi label yang lebih khusus, misalnya permintaan maaf, keluhan, pujian, undangan, janji atau permohonan. Atau dengan istilah lain untuk tindak tutur yang berlainan digunakan untuk maksud komunikatif penutur untuk menghasilkan tuturan. Penutur biasanya berharap maksud komunikatifnya akan dimengerti oleh pendengar. Penutur dan pendengar biasanya terbantu oleh keadaan di sekitar lingkungan tuturan itu. keadaan semacam ini termasuk juga tuturan -tuturan yang lain disebut dengan peristiwa tutur ${ }^{5}$.

Menurut Chaer tindak tutur adalah adanya tuturan yang bersifat psikologis dari seseorang dan yang dilihat dari makna tindakan dalam tuturannya itu. Sekumpulan tindak tutur akan membentuk speech event atau suatu peristiwa tutur. Kemudian, tindak tutur dan peristiwa tutur akan menjadi dua gejala yang terdiri pada satu proses, yaitu komunikasi. Jadi, tindak tutur adalah adanya aktivitas seseorang dalam berbahasa terhadap lawan tutur dalam rangka menyampaikan sesuatu. Makna yang terdapat dalam komunikasi tersebut tidak hanya dapat dimengerti berdasarkan bahasa yang digunakan dalam bertutur tersebut tetapi juga ditentukan oleh aspek-aspek komunikasi secara komprehensif, termasuk aspek-aspek situasional komunikasi ${ }^{6}$.

Menurut Austin, "tindak tutur ialah "sepenggal tutur yang dihasilkan sebagai bagian dari interaksi social". Pernyataan ini sangat bertentangan dengan contoh-contoh kalimat yang telah diberikan oleh para linguis dan filosof yang lepas dari konteks. Budaya kita mengandung seperangkat konsep

${ }^{5}$ Geoffrey Leech, Prinsip-prinsip Linguistik, Terj. M.D.D Oka, (Jakarta: Universitas Jakarta, 1993), hlm. 82.

${ }^{6}$ Abdul Chaer, Kesantunan Berbahasa, ( Jakarta: Rineka Cipta, 2010), h. 27 
untuk memilah milah interaksi social tadi. Contohnya, kita membedakan antara "kerja" dan "bermain" atau "bersenang-senang" atau " bersantai", antara "bermain" dan "bertanding". Begitupula, terdapat banyak konsep budaya, dengan berbagai label bahasa, untuk berbagai tindak tutur. Contohnya, makna berjanji dalam konsep budaya tertentu"7.

Menurut Austin tindak lokusi adalah "the act of saying something" melakukan tindakan untuk mengatakan sesuatu. Dalam tindak lokusi terkandung makna literal. Misalnya: "It is hot here", makna lokusi yang terkandung dalam kalimat tersebut berhubungan dengan suhu udara di tempat itu. Contoh lain "Saya lapar", "Saya" diartikan sebagai orang pertama tunggal (si penutur), dan "lapar" mengacu pada "perut kosong yang butuh diisi", tanpa adanya maksud untuk meminta makanan. Dengan kata lain, tindak tutur lokusi ialah tindak tutur yang menjelaskan sesuatu dalam arti "berkata" atau bentuk kalimat tindak tutur yang bermakna dan dapat dipahami ${ }^{8}$.

Menurut Austin ilokusi ialah pernyataan yang mempunyai kekuatan tertentu (konvensional), seperti: menginformasikan, menyuruh, mengingatkan, dan sebagainya. Dengan kata lain, tindak ilokusi adalah tindak dalam menerangkan sesuatu. Searle mengatakan bahwa tindak ilokusi ialah melakukan tindak itu sendiri, seperti: menjelaskan, bertanya, menyuruh, dan berjanji ${ }^{9}$.

Austin menjelaskan tentang tindak tutur ilokusi, yakni tindak tutur yang terdiri dari maksud dan fungsi atau daya tuturan ${ }^{10}$. Rohmadi menjelaskan bahwa tindak ilokusi adalah tindak tutur yang difungsikan untuk menginformasikan atau menyampaiakan sesuatu dan digunakan untuk

${ }^{7}$ Sumarsono, Sosiolinguistik, (Yogyakarta: SABDA, 2014), h. 323.

${ }^{8}$ J.L. Austin, How to Do Things with Words, (Cambridge: Harvard University Press, 1955), h. 94-97

${ }^{9}$ J.L. Austin, How to Do Things with Words, (Cambridge: Harvard University Press, 1962), h. 10.

${ }^{10}$ Ibid., 
melakukan sesuatu, disebut juga the act of doing something ${ }^{11}$. Teori Austin mendapatkan kritikan dari Searle yakni muridnya sendiri. Berdasarkan suku pandang Searle sebagaimana yang telah dikutip oleh Rustono teori yang dibentuk oleh Austin terdapat hal yang membingungkan antara verba dan tindakan, terlalu banyak tumpang tindih dalam teori tersebut, terlalu banyak heterogenitas dalam kategori dan yang paling penting adalah tidak adanya prinsip klasifikasi yang konsisten. Kemudian Searle menggolongkan tindak tutur menjadi lima kelompok berdasarkan fungsinya, yaitu representatif, direktif, komisif, ekspresif, dan deklaratif ${ }^{12}$. Sebagaimana yang dijelaskan oleh Kreidler bahwa pada tindak tutur representatif (disebut juga asertif) para penulis dan penutur memakai bahasa untuk menjelaskan bahwa mereka mempercayai atau mengetahui sesuatu. Bahasa asertif ada kaitannya dengan fakta. Tujuannya adalah menyampaikan informasi. Tindak tutur ini ada kaitannya dengan pengetahuan, data, apa yang ada atau diadakan, atau telah terjadi atau tidak terjadi. Dengan demikian, tindak tutur asertif bisa benar bisa salah dan biasanya dapat diverifikasi atau disalahkan ${ }^{13}$.

Austin dan Searle secara pragmatis mengemukakan bahwa setidaknya ada tiga jenis tindakan yang mungkin diwujudkan oleh penutur di dalam berbahasa, yaitu: (1) tindak mengungkapkan sesuatu (lokusioner/lokusi), (2) tindak melakukan sesuatu (ilokusioner/ilokusi), dan (3) tindak mempengaruhi lawan bicara (perlokusioner/ perlokusi). ${ }^{14}$.

${ }^{11}$ Muhammad Rohmadi, Pragmatik: Teori dan Analisis, ( Yogyakarta: Lingkar Media, 2004), h. 31

${ }^{12}$ Rustono, Pokok-pokok Pragmatik, (Semarang: IKIP Semarang Press, 1999), h. 39

${ }^{13}$ Charles W Kreidler, Introducing English Semantics, (New York: Routlede, 1998), h. 183.

${ }^{14}$ J.L.Austin, How to Do Things with Words, (Cambridge: Harvard University Press, 1962), h. 10. 


\section{Metode Penelitian}

Metode penelitian merupakan alat prosedur dan teknik yang dipilih dalam melaksanakan penelitian. ${ }^{15}$ Untuk melaksanakan tujuan penelitian, penulis menggunakan pendekatan pragmatik dengan menerapkan metode deskriptif kualitatif. Metode deskriptif ini dipilih untuk memberikan gambaran secermat mungkin dalam melihat dan mengkaji fenomena kebahasaan yang berkaitan dengan potret peristiwa tutur dan tindak tutur yang terjadi dalam kegiatan Forum Kerukunan Umat Beragama di Lampung Timur. Metode ini digunakan untuk menghasilkan data deskriptif berupa bentuk verbal yang dihasilkan dalam kegiatan tersebut.

Pada bagian ini peneliti memaparkan teknik penelitian yang penulis tempuh, mulai dari teknik pengumpulan data, instrumen penelitian, teknik pengolahan data sampai pada teknik analisis data yang penulis gunakan. Berikut uraian masing-masing poin di atas:

Dalam mengumpulkan data, penulis menggunakan dua teknik yakni; teknik simak dan cakap ${ }^{16}$. Kedua teknik ini digunakan untuk mendapatkan data di lapangan secara akurat. Secara ringkas semua teknik pengumpulan data yang akan digunakan dalam penelitian ini penulis sajikan dalam bentuk bagan sebagai berikut:

Berikut pemaparan dari teknik pengumpulan data;

a. Teknik simak

1) Mengamati peristiwa tutur

2) Melakukan perekaman data dengan cara menyimpan alat rekam berupa tipe rekorder atau alat sejenis untuk

\footnotetext{
${ }^{15}$ Fatimah Djajasudarma,Metode Linguistik Ancangan Metode Penelitian dan Kajian (Bandung: Eresco,1993), hlm. 3.

${ }^{16}$ Mahsun, Metode Penelitian Bahasa, (Jakarta: Raja Grafindo Persada, 2005), hlm. 242 .
} 
menyadap peristiwa tutur dan tindak tutur dalam kegiatan Forum Kerukunan Umat Beragama.

b. Teknik cakap

1) Terlibat percakapan secara langsung dengan para anggota Forum Kerukunan Umat beragama

2) Perekaman data dengan cara menyimpan alat rekam untuk menjaga kemurnian data

3) Memberikan pancingan agar data yang dibutuhkan dapat terungkap.

Instrumen yang digunakan dalam pengumpulan data di lapangan berupa alat rekam dan catat.

1) Alat Rekam

Alat ini digunakan untuk menyadap peristiwa tutur dan tindak tutur dalam kegiatan Forum Kerukunan Umat Beragama. Dengan alat ini peneliti dapat melihat realita yang terjadi dalam setiap kegiatan melalui tuturan sekaligus dapat mengumpulkan data sebanyak-banyaknya berupa data verbal.

2) Catat

Mencatat adalah merupakan hal yang wajib dilakukan oleh peneliti untuk mengumpulkan dan mendokumentasikan data melalui pencatatan.

Dalam menggunakan teknik ini peneliti menggunakan langkah-langkah yang tersusun secara tertib. Berikut langkahlangkah yang akan peneliti lakukan:

a. Transkrip data yang mengandung tindak tutur terlebih dahulu ditranskripsikan ke dalam bahasa tulis.

b. Memasukkan data hasil trnaskrip ke dalam kartu data 
c. Analisis data berdasarkan beberapa aspek yang telah penulis lakukan

d. Pengklasifikasian data berdasarkan jenis peristiwa tutur dan tindak tutur.

\section{Pembahasan}

Berikut ini beberapa ungkapan tindak tutur perlokusi atau yang disebut dengan the act of affecting someone dengan pengaruh penutur dan mitra tutur tergambar seperti kalimat di bawah ini:

1. Assalamu'alaikum, salam sejahtera, om swastiastu Tuturan pada data satu diutarakan oleh seseorang kepada komunitas perkumpulannya, maka memiliki ilokusi yang bermakna "menyatakan" dalam bentuk asertif, adapun efek perlokusinya agar semua peserta merasa dianggap kehadirannya dan menjawab ucapan pembukaan penutur.

Di sisi lain ketikan tuturan tersebut dituturkan secara tidak langsung terjalin hubungan kebersamaan dan kerja sama dalam berkomunikasi yang tentunya hal itu tidak mengabaikan kesopanan dan keramah tamahan di antara mereka. Dengan prinsip kerja sama dalam berkomunikasi yang telah dibangun melalui tuturan antara penutur dengan mitra tutur berrarti penutur menggunakan maksim kearifan.

2. "Mari kita buka rapat kita pada siang hari ini, untuk yang beragama Islam mari kita buka dengan membaca lafadz al-basmalah"

Tuturan pada data kedua di atas dituturkan oleh seorang modirator ketika membuka rapat pertemuan antar pemuda lintas agama. Tuturan tersebut bukan sekedar tuturan yang tidak memiliki makna yang tersirat namun sebagai tuturan yang memiliki ilokusi yang bermakna "menyatakan" dalam bentuk asertif adapun efek perlokusinya adalah setiap peserta rapat merespon apa yang telah dituturkan oleh penutur. Dengan sengaja penutur mengungkapkan 
tuturannya dengan menggunakan "maksim cara" dengan artian bahwa penutur menggunakan cara-cara tersendiri untuk menjalin kebersamaan dan kesopanan di antara mereka dan tentunya menjaga agar tdak menyinggung perasaan secara langsung.

3. "Monggo romo dipersilahkan"

Seorang modirator mempersilahkan kepada sang romo maju ke atas mimbar untuk memberikan sambutan. Tuturan di atas memiliki ilokusi yang bermakna "menyatakan" dalam bentuk asertif. Adapun bentuk perlokusinya adalah sang romo bergegas menuju mimbar utama untuk memberikan sambutan. Tuturan tersebut sengaja dituturkan oleh modiratur untuk menghormati dan menghargai status dan kedudukan sang romo dalam agamanya. Dalam tuturan tersebut terjalin prinsip kerja sama antara penutur dengan mitra tutur dalam berkomunikasi.

4. "Gebrakan yang dilakukan oleh penghayat kepercayaan kepada Tuhan Yang Maha Esa"

Tuturan keemapt diatas dituturkan oleh salah satu audien yang menghadiri kegiatan Sosialisasi Perundangan yang Berkaitan dengan Prikehidupan Penghayat Kepercayaan terhadap Tuhan yang Maha Esa. Tuturan di atas memiliki ilokusi yang bermakna "mengingatkan" dalam bentuk asertif. Adapun bentuk perlokusinya adalah melakukan berbagai kegiatan untuk mensosialisasikan tentang penghayat kepercayaan kepada Tuhan Yang Maha Esa. Tuturan tersebut menggunakan prinsip kerja sama antara penutur dengan lawan tutur. Maksim cara ini digunakan untuk menggugah kesemangatan para penghayat kepercayaan Kepada Tuhan Yang Maha Esa.

5. "Pembinaan kepada masyarakat"

Dalam kegiatan rapat rutin Forum Kerukunan Umat Beragama (FKUB), salah satu peserta rapat mengungkapkan tuturan di atas dengan maksud penggunaan istilah pembinaan adalah pembinaan kepribadian yang mandiri 
dan sempurna serta dapat bertanggungjawab. Tuturan di atas memiliki ilokusi yang bermakna "memerintah" yang berbentuk direktif. Adapun bentuk perlokusinya adalah megajak atau mengarahkan kepada setiap individu untuk melakukan pembinaan kepada masyarakat dalam bersosialisasi dan menjaga kerukunan umat beragama. Penggunaan tuturan di atas sengaja dituturkan oleh penutur untuk menjalin kerja sama yang baik agar tercipta keberlangsungan hidup yang sejahtera dengan prinsip sopan yang menggunakan maksim kesepakatan diharapkan mampu mengajak seluruh lapisan masyarakat untuk melakukan pembinaan.

6. "Konsolidasi pengembang penghayat kepercayaan kepada Tuhan Yang Maha Esa"

Tuturan di atas mengandung makna memperteguh atau memperkuat, perhubungan, persatuan, dan sebagainya antara pengembang penghayat kepercayaan kepada Tuhan Yang Maha Esa. Tuturan di atas dituturkan oleh salah satu peserta audien ketika menghadiri sosialisasi perundangan yang Berkaitan dengan Prikehidupan Penghayat Kepercayaan terhadap Tuhan yang Maha Esa. Tuturan di atas memiliki ilokusi yang bermakna "memerintah" yang berbentuk direktif. Adapun bentuk perlokusinya adalah megajak atau mengarahkan kepada setiap individu untuk saling mengukuhkan dan memperat hubungan di antara mereka. Prinsip kerja sama yang dibangun melalui penutur ini terciptalah prinsip soapan yang telah dilakukan oleh penutur kepada mitra tutur, dimana prinsip sopan yang digunakan adalah maksim kesepakatan.

7. "Untuk berproses menjaga kebhinekaan"

Tuturan di atas disampaikan oleh penutur kepada seluruh anggota Forum Kerukunan Umat Beragama (FKUB). Tuturan di atas memiliki ilokusi yang bermakna "menyarankan" yang berbentuk asertif. Adapun bentuk perlokusinya adalah setiap individu terus menjaga kebhinekaan di dalam 
kehidupan bermasyarakat. Kebersamaan yang dibangun melalui tuturan tersebut penutur menggunakan maksim kualitas untuk menjalin kerjasama antara penutur dengan kitra tutur.

8. "Kerukunan adalah bersifat dinamis maka harus dipelihara"

Tuturan di atas adalah tuturan yang dilontarkan oleh salah satu anggota FKUB dalam rapat rutin. Tuturan di atas memiliki ilokusi yang bermakna "merekomendasi" yang berbentuk direktif. Maka memiliki perlokusi secara tidak langsung menginformasikan bahwa kita harus saling mejaga kerukunan antar umat beragama. Kerja sama yang dibangun penutur dengan mitra tutur terjalin baik dengan adanya maksim kesopanan yang berupa kerendahan hati untuk memohon kepada mitra tutur.

9. "Dengan wadah (FKUB) sudah ada keterbukaan antara pengurus lintas agama"

Tuturan tersebut dituturkan oleh penutur dalam kegiatan temu tokoh lintas agama. Tuturan di atas memiliki ilokusi yang bermakna "menyatakan" yang berbentuk asertif. Maka memiliki perlokusi secara tidak langsung menginformasikan bahwa agara saling menjalin komunikasi anatar umat beragama yang tentunya dengan terjalinnya kerja sama antar pengurus akan berdamapak pada anggota dan masyarakat sekitar. Prinsip kerja sama antara penutur dengan mitra tutur yang mengandung maksim kesepakatan yang akan terus dilakukan dan dipertahankan oleh anggota FKUB demi menjalin hubungan antar sesama.

10. "Mensosialisasikan dengan kata-kata yang tidak menyinggung orang lain"

Tuturan pada data di atas diutarakan oleh penutur kepada ketua perkumpulan, maka memiliki ilokusi secara tidak langsung menginformasikan bahwa ketika mensosialsasikan suatu kegiata atau mengajak kepada siapapun harus dengan kata-kata yang tidak menyinggung orang lain. Maka tuturan di 
atas memiliki ilokusi yang bermakna "memerintah" yang berbentuk direktif. Adapun efek perlokusinya adalah setiap idividu akan saling menjaga dalam setiap tuturan yang dituturkan. Dalam menjaga tuturan pihak penutur menggunakan maksim kerendahan hati untuk mengajak kepada orang lain.

11. "Kita perlu mengedepankan kebersamaan"

Tuturan pada data di atas diutarakan oleh penutur kepada ketua perkumpulan, maka memiliki ilokusi secara tidak langsung menginformasikan bahwa kepentingan umum di atas kepentingan individu. Tuturan di atas memiliki ilokusi yang bermakna "mrekomendasikan" yang berbentuk direktif. Adapun efek perlokusinya adalah setiap idividu akan saling mengutamakan kepentingan bersama di atas kepentingan individu. Prinsip kerja sama yang menggunakan maksim hubungan yang dijalin antara penutur dengan mitra tutur tentunya memiliki prinsip kesopanan yang sudah dibangun melalui penutur.

12. "Sekecil apapun fungsi manusia harus dihargai"

Sebuah ungkapan di atas menggambarkan toleransi yang dibangun anatar sesama. Tuturan di atas memiliki ilokusi yang bermakna "memerintah" yang berbentuk direktif. Adapun efek perlokusi dari tuturan tersebut adalah setiap individu harus terus menjaga keharmonisan antar umat beragama. Maksim kerendahan hati yang telah diungkapkan oleh penutur sangat mempengaruhi prinsip kerja sama yang dibangun melalui tuturan.

13. "FKUB bukan kelompok yang punya musuh dan tantangan tetapi mengajak umat bersam-sama"

Ungkapan di atas sebuah pernyataan yang diungkapkan oleh ketua FKUB untuk meyakinkan kepada seluruh anggota bahwa FKUB selalu bergandeng tangan. Tuturan di atas memiliki ilokusi yang bermakna "menasehati" yang berbentuk direktif. Adapun efek perlokusi dari tuturan tersebut adalah tidak saling bermusuhan antar umat beragama. Maksim cara yang dilakukan oleh 
penutur untuk menjalin kerja sama dalam berkomunikasi terjalin dengan baik didukung dengan penggunaan maksim kerendahan hati dalam mengajak dan menasehati orang lain.

14. "Teknologi berperan penting dalam menyambung informasi dan isuisu tentang agama"

Salah satu anggota menuturkan ungkapan di atas bahwa sangat pentingnya sebuah teknologi untuk menggali informasi apapun terutama yang berkaitan dengan isu-isu keagamaan. Tuturan di atas memiliki ilokusi yang bermakna "merekomendasikan" yang berbentuk direktif. Adapun efek perlokusi dari tuturan tersebut adalah setiap individu harus melek teknologi untuk menunjang informasi. Ajakan yang berupa merekomendasikan kepada setiap individu untuk menggali informasi melalui teknologi sangat santun dengan menggunakan maksim cara di atas terjalin kerja sama antara penutur dengan mitra tutur sehingga secara tidak langsung melului ungkapan tersebut menggunakan maksim kerendahan hati seorang penutur.

15. "Kita harus mempertontonkan kerukunan bukan percekcokan"

Tuturan di atas disampaikan oleh salah satu anggota FKUB dalam kegiatan rapat rutin di FKUB. Tuturan di atas memiliki ilokusi yang bermakna "menasehati" yang berbentuk ungkapan direktif. Adapun efek perlokusi dari tuturan tersebut adalah bekerja sama saling bergandeng tangan. Ungkapan yang berupa nasehat di atas menunjukkan maksim kerendahan hati seorang penutur hal tersebut terbukti dengan nasehat yang terkesan tidak langsung menasehati namun menghimbau untuk mempertontonkan kerukunan. Sehingga terjalin prinsip kerja sama yang baik antara penutur dengan mitra tutur.

16. "Menambahkan keakraban kita dalam memperkokoh persatuan dan kesatuan harmonisasi dalam perbedaan, susku, agama, ras, dan golongan dalam bingkai negara kesatuan Republik Indonesia". 
Ungkapan seorang penutur di atas memiliki ilokusi yang bermakna "menyatakan" yang berbentu asertif. Adapun efek perlokusi dari tuturan tersebut adalah tidak saling mengucilkan atau merendahkan tetapi saling toleransi. Ungkapan yang berupa pernyataan di atas menunjukkan maksim kesepakatan yang dibangun seorang penutur untuk saling menciptakan kesatuan dan persatuan. Sehingga terjalin prinsip kerja sama yang baik antara penutur dengan mitra tutur.

17. "Ormas menjadi mitra pemerintah"

Ungkapan seorang penutur di atas memiliki ilokusi yang bermakna "menyarankan" yang berbentuk ungkapan asertif. Efek perlokusi dari tuturan tersebut adalah menyalurkan aspirasi masyarakat. Ungkapan yang berupa ajakan di atas menunjukkan maksim simpati berupa ajakan kepada masyarakat untuk bersatu dengan ormas-ormas keagamaan karena aspirasi masyarakat akan langsung disampaikan melalui ormas tersebut. Di sisi lain penggunaan prinsip sopan yang berupa maksim kearifan yang dituturkan penutur menjadikan komunikasi terjalin dengan baik.

18. "Semoga Yang Maha Esa selalu melimpahkan kebahagiaan kepada kita semua"

Seorang romo menyampaikan dalam pidatonya kepada anggota FKUB harapan tentang kelimpahan kebahagiaan buat mereka semua. Tuturan diatas memiliki ilokusi yang bermakna " menyatakan "dalam bentuk asertif. Adapun perlokusinya adalah para anggota FKUB menjawab pernyataan tersebut dengan mengucapkan "amin" yang dilontarkan oleh para Muslim dan ucapan "amen" dilontarkan oleh para non Muslim. Tuturan tersebut dilontarkan oleh romo untuk memberikan doa kepada seluruh anggota FKUB tanpa membedakan agama masing-masing anggota. Dalam tuturan tersebut terjalin prinsip kerja sama antara penutur dan mitra tutur dalam berkomunkasi. Prinsip kerjasamanya ketika anggota langsung menjawab tuturan tersebut dengan 
mengucapkan "amin". Prinsip kerjasama tersebut masuk dalam kategori maksim cara.

19. "Halo assalamualikum selamat pagi"

Tuturan diatas disampaikan oleh ketua rapat dalam perkumpulan komunitas FKUB se Lampung Timur. Tuturan tersebut bukan sekedar tuturan yang tidak memiliki makna yang tersirat namun sebagai tuturan yang memiliki ilokusi yang bermakna "menyatakan" dalam bentuk asertif. Adapun makna perlokusi dari tuturan tersebut adalah sebagian anggota ada yang menjawab "wassalamualikum" dan sebagian anggota menjawab "selamat pagi". Tuturan tersebut tidak terfokus sapaan terhadap orang muslim saja, melainkan tuturan selamat pagi untuk memberikan sapaan terhadap orang non Muslim. Jadi tuturan tersebut menyangkut semua sapaan kepada seluruh anggota dalam komunitas tersebut tanpa adanya kecenderungan terhadap satu suku ras atau agama. Di sisi lain ketikan tuturan tersebut dituturkan secara tidak langsung terjalin hubungan kebersamaan dan kerja sama dalam berkomunikasi yang tentunya hal itu tidak mengabaikan kesopanan dan keramah tamahan di antara mereka. Dengan prinsip kerja sama dalam berkomunikasi yang telah dibangun melalui tuturan antara penutur dengan mitra tutur berrarti penutur menggunakan maksim kearifan.

20. "Kita harus memelihara kebersamaan kita"

Tuturan tersebut disampaikan oleh salah satu anggota rapat. Tuturan tersebut guna untuk menekankan adanya toleransi sesama anggota untuk memelihara kebersamaan mereka. Jadi tuturan diatas mengandung makna ilokusi "menyarankan" dalam bentuk asertif. Selain itu makna perlokusi dari tuturan tersebut adalah adanya tindakan yang dilakukan oleh mitra tutur seperti, menjalin silaturahmi diluar forum rapat, saling mengunjungi satu sama lain. Secara tidak langsung tuturan tersebut mengandung unsur kerja sama antara penutur dan mitra tutur. Adapun kerjasama yang dilakukan termasuk 
maksim hubungan. Misalnya, mitra tutur melakukan kunjungan silaturahmi kesesama anggota setelah forum tersebut berakhir tanpa mengabaikan kesopanan dalam bersilaturahmi.

21. "Kita buka acara ini dengan penuh rahmat dari Tuhan yang Maha Esa"

Tuturan yang ke tujuh diutarakan oleh ketua rapat dalam perkumpulan komunitas FKUB se Lampung Timur. Tuturan tersebut memiliki makna ilokusi "menyatakan" dalam bentuk asertif. Adapun makna perlokusi dari tuturan tersebut adalah setiap anggota merespon tuturan yang telah disampaiakan oleh ketua. Penutur sengaaja menggunakan "maksim cara" dalam artian penutur menggunakan cara tersebut untuk menjaga toleransi sesama anggota, dengan tujuan semua anggota menjawab sesuai keyakinan mereka masing-masing. Secara langsung penutur menjaga kesopanan agar tidak menyinggung sesama anggota yang berbeda-beda agama.

22 "Forum ini adalah forum untuk mempersatukan dan mempersaudarakan"

Tuturan diatas adalah tuturan yang dituturkan oleh penutur terhadap mitra tutur. Tuturan tersebut mengandung makna ilokusi "mengingatkan" dalam bentuk asertif. Tuturan diatas juga mengandung makna perlokusi yang artinya, adanya efek tindakan dari mitra tutur yang saling toleransi satu sama lain untuk menjaga persatuan dan persaudaraan dalam forum kerukunan umat beragama. Secara tidak langsung adanya kerjasama antara penutur dan mitra tutur untuk saling mendorong adanya hubungan yang baik antar sesama. Prinsip kerjasama tersebut termasuk dalam "maksim hubungan". Adapun kesopanan yang mereka jaga adalah saling toleransi antar umat beragama dalam tali persatuan dan persaudaraan. 


\section{E. Kesimpulan}

Berdasarkan hasil penelitian dan pembahasan dapat disimpulkan bahwa tindak tutur yang terjadi dalam Forum Kerukunan Umat Beragama (FKUB) Lampung Timur adalah dalam seluruh kegiatan yang telah dilakukan FKUB terjadi tindak tutur antar penutur dengan mitra tutur. Terjadinya tindak tutur tersebut dapat dilihat dari seluruh kegiatan yang telah dilakukan oleh FKUB. Dari beberapa kegiatan tersebut terdapat tiga bentuk tindakan yaitu:

Tindak tutur lokusi ialah tindak tutur yang menjelaskan sesuatu dalam arti "berkata" atau bentuk kalimat tindak tutur yang bermakna dan dapat dipahami. Dengan kata lain bahawa Tindak lokusi merupakan tindak tutur yang mudah untuk diidentifikasi karena tidak memerlukan konteks tuturan yang tercakup dalam situasi tutur.

Tindak tutur ilokusi adalah tindak tutur yang difungsikan untuk menginformasikan atau menyampaikan sesuatu dan digunakan untuk melakukan sesuatu. Sedangkan tindak tutur perlokusi adalah tindak tutur yang memberikan daya pengaruh atau efek bagi mitra tutur yang mendengarkannya. 


\section{Daftar Pustaka}

Austin, J. (1962). How to Do Things with Words. Cambridge: Harvard University Press.

Burhanuddin, \& Sumarlam. (2015). Strategi kesopanan berbahasa Presiden joko widodo; potret tindak Tutur penanganan masalah Sosial-politik bangsa . Adabiyyāt, Vol. XIV, No. 2, Desember 2015, 189.

Chaer, A. (2010). Kesantunan Berbahasa. Jakarta: Rineka Cipta.

Djajasudarma, F. (1993). Metode Linguistik Ancangan Metode Penelitian dan Kajian . Bandung: Eresco.

Kreidler, C. W. (1998). Introducing English Semantics. New York: Routlede.

Leech, G. (1993). Prinsip-prinsip Linguistik . Jakarta: Universitas Jakarta.

Mahsun. (2005). Metode Penelitian Bahasa. Jakarta: Raja Grafindo Persada.

Purba, A. (2011). ,Tindak Tutur Dan Peristiwa. Purba, Vol. 1 No. 1 Desember 2011,77 .

Ristiyani. (2016). Tindak Tutur Santun Sebagai Strategi Pemilihan Bahasa Untuk Komunikasi Konselor Yang Efektif . Jurnal Konseling GUSJIGANG Vol. 2 No. 1 (Januari-Juni 2016) , 49.

Rohmadi, M. (2004). Pragmatik: Teori dan Analisis. Yogyakarta: Lingkar Media.

Rustono. (1999)., Pokok-pokok Pragmatik. Semarang: IKIP Semarang Press.

Sumarsono. (2014). Sosiolinguistik. Yogyakarta: SABDA.

Wahyudi. (2012). Jenis dan fungsi tindak tutur dosen dalam interaksi pembelajaran bahasa arab di UIN Malang. ThaqÃfiyyÃT, Vol. 13, No. 2, Desember 2012, 358. 